\title{
Discovering sources of inequality in transition economies: a case study of rural Vietnam
}

\author{
Vasco Molini · Guanghua Wan
}

Received: 19 July 2006/ Accepted: 4 March 2008/Published online: 19 March 2008

(C) The Author(s) 2008

\begin{abstract}
Applying the recently developed inequality accounting framework, we quantify contributions of fundamental variables to consumption inequality in rural Vietnam. It is found that major determinants of the inequality include location, education, infrastructures. From 1993 to 1998, the contributions of education, physical capital, labour and community infrastructure to total inequality increased while those of land and credit access declined. Ethnicity is found to play a decreasing role in composing total inequality. Policy implications are discussed.
\end{abstract}

Keywords Inequality decomposition · Transition · Asia $\cdot$ Vietnam

JEL Classification $\mathrm{O} 15 \cdot \mathrm{C} 43 \cdot \mathrm{P} 24$

\section{Introduction}

During the 1990s, the Vietnamese economy has grown at a particularly fast pace, (an average $+7 \%$, WB 2004). Yet, growth came at the expenses of the egalitarian income distribution inherited from the socialist period. Income imbalances started to become evident not only between different regions but also within regions, mainly due to the increasing gap between urban and rural areas.

\footnotetext{
V. Molini ( $\bowtie)$

Centre for World Food Studies (SOW-VU), De Boelelaan 1105, 1081 HV Amsterdam,

The Netherlands

e-mail: v.molini@sow.vu.nl

G. Wan

Yunnan University of Finance and Economics, Longquan Lu, People's Republic of China e-mail: guanghuawan@yahoo.com
} 
By contrast, in the same period the income inequality in rural areas remained substantially unmodified (see Table 1). While the increasing urban rural gap has attracted the attention of many scholars (Glewwe et al. 2002; Baulch and Minot 2004 inter alia), the issue of stability of income distribution in rural areas has been less analyzed, although almost $80 \%$ of the population was residing there during the $1990 \mathrm{s.}^{1}$ In particular, a part for few exceptions (Benjamin and Brandt 2004), it has been overlooked the nexus between key reforms like the de-collectivization of land and the liberalization of crop markets and their ultimate impact on the income distribution.

The aim of this paper is precisely filling this gap. We plan to investigate the sources of rural inequality and quantify their contributions. Next, through an intertemporal comparison between the two available surveys (1993-1998), we try to interpret the modification of income inequality determinants. The so-conducted analysis, besides the validity on its own, it is useful to both foresee future trends and provide useful insights to policy makers. In the first case, once the main determinants are identified and quantified, it becomes easier predicting likely changes in the overall inequality. In the second case, a quantitative analysis on inequality determinants might be used in deciding the tools and the targets for redistributive policies. For example, government can better justify infrastructure investments in poor regions if location is found to be dis-equalising and contributing for a significant amount to total inequality.

The analytical method used in this paper is a combination of regression-based decomposition of Wan (2004) with the Shapley's value technique of Shorrocks (1999, Unpublished Manuscript). Regression-based decomposition was initiated by Oaxaca (1973) and Blinder (1973), which has been largely used to analyze discrimination in the labour market. The Shapley's value technique is based on cooperative game theory and is a general decomposition framework which can be used in contexts other than inequality decomposition. This combination introduces flexibility in the specification of the underlying income or consumption function and in the choice of inequality measures.

The paper is organised as follows. Sections $2-4$ provide a general overview on initial conditions, economic reforms and income distribution of Vietnam from late 1980s to the 1990s. In Sect. 5, we present the Shapley's value decomposition and the data used while in Sects. 6 and 7 are discussed the econometric and the decomposition results, respectively. Section 8 concludes.

\section{Transition and inequality: the initial conditions}

The process of transition has been widely analysed since the collapse of the Soviet block (Lavigne 1999; Roland 2000 inter alia). In particular, after the dramatic increase of inequality in most of the former socialist countries, the nexus between transition and inequality has been studied in depth (Cornia and Popov 2001; Flemming and Micklewright 1999; Milanovic 1995, 1998).

\footnotetext{
${ }^{1}$ According to the World Bank (2004), the rural population accounted in 2003 to $74 \%$ of the total population.
} 
Table 1 Inequality measures and their decomposition

\begin{tabular}{lll}
\hline Inequality indexes & 1993 & 1998 \\
\hline Gini's coefficient & 0.32 & 0.355 \\
Theil's index GE(0) & 0.176 & 0.20 \\
Decomposition of Theil's index & & \\
Urban/rural & & \\
$\quad$ GE(0) within & 0.136 & 0.139 \\
$\quad$ GE(0) between & 0.04 & 0.061 \\
Within rural and urban & & \\
Rural population share & $80 \%$ & $20 \%$ \\
Urban population share & $24 \%$ & $76 \%$ \\
$\quad$ Gini rural & 0.273 & 0.272 \\
$\quad$ Gini urban & 0.336 & 0.342 \\
GE(0) within rural & 0.1232 & 0.1227 \\
GE(0) within urban & 0.1853 & 0.1911 \\
\hline
\end{tabular}

Source: Authors calculation and VLSS 1993-1998

The rise in inequality, in fact, has been much bigger than expected from a normal process of liberalisation. Before the transition, socialist countries faced on average lower levels of inequality where computing the inequality indexes on gross income. Considering net income after taxes, the level of inequality of many socialist countries approached those of most advanced social-democratic countries (e.g. Finland and Sweden). Differently from the latter, low levels of inequality were achieved not through tax redistribution or transfers but through ex-ante mechanisms (Cornia and Popov 2001).

Cornia and Popov (2001) underline three main mechanisms: centralized wage regulation, collective ownership of means of production and free access to healthcare and school provision. The transition to market economy and the withdrawal of the State from the economy, although with big differences in timing, sequencing and outcomes among transition countries, determined the abandonment of this kind of framework. In almost all countries, allowing market forces to operate freely led to an increase of inequality (Milanovic 1998). There is a general consensus between scholars on this issue. More debated are the causes and the reasons why, starting from similar inequality levels, transition countries performed differently (for wage inequality see Boeri 2000; Lu and Verme 2002).

Vietnam is an interesting case of successful transition with a moderate increase of inequality during and after the reforms. First, it is worth analysing the initial conditions and the specific reforms that made Vietnam a peculiar case in the transition economies landscape.

At the beginning of the transition process, alongside the transformation from a socialist into a market economy, Vietnam had to cope with the problem of development and industrialization (Dutta 1995). This predominance of the primary sector had two important implications. The first pertains to the nature of potential inequality, and the other to the type of transition process implemented. ${ }^{2}$

\footnotetext{
${ }^{2}$ Agriculture is still today the biggest sector in terms of employment (67.5\% of the total labour force in 2001) and accounts for about $21 \%$ of total GDP (WB 2004).
} 
In a less industrialized country, land concentration is one of the main determinants of income distribution. A fair land distribution has a positive effect on this latter and preserves social stability too, a crucial element to determine investment propensity. Alesina and Perotti (1996) use this argument to explain different performance of Latin American and East Asian countries. Having implemented egalitarian land reforms after the Second World War, Taiwan and South Korea achieved the maintenance of a level of socio-political stability. Conversely, the inability of Latin America to reducing land concentration, protracted until now an unfair distribution of assets generating strong income inequality and compromised their growth performance through a continuous social instability.

The way de-collectivisation has been implemented in Vietnam during early 1990s (Sect. 3), strongly affected income distribution during 1990s and will probably do it for a long period. The limited importance of manufacturing and services before the reforms, conditioned the pattern of reforms too.

In contrast to the other transition economies, during the transition to a market economy Vietnam (and China) did not experience a collapse of the GDP protracted for a long period and a mass increase of unemployment: GDP's growth simply decelerated to 5\% during 1990-1991. Once macroeconomic stabilization was achieved in early 1990s (Dutta 1995), growth accelerated again averaging 9\% over 1992-1995. Because of this high growth and initial reforms of the tax system, tax revenue increased rapidly after 1991. The government was therefore able to restore the investment and social expenditures cut during the austerity period (1986-1989).

According to various authors, a low level of economic development (low-level capital/output ratios, Cornia and Popov 2001) or less economic complexity (Blanchard and Kremer 1997; Roland 2000) might have given an advantage to these economies. This because the resources to be reallocated from declining sectors to expanding ones were smaller and so was the level of distortion. In the case of Blanchard and Kremer's model, in more complex economies, a bigger output fall occurs due to disorganisation of production linkages and the greater difficulties met in reconstructing them when several actors participate in the production chain and asymmetric information is widespread.

Vietnam entered the process of transition with a low level of capital accumulation, limited importance placed on the state controlled industrial sector and with land still representing one of the most important asset for most of the households (Kerkvliet and Selden 1998). This gave the country indubitable advantages in terms of speed and costs of transition while on the other side, made the de-collectivisation in the agriculture a much more crucial reform than in other more industrialised transition economies.

\section{The reforms: 1986-1998}

One of the main consequences of the reform process (Doi Moi) introduced by the 6th Congress of the Communist party in 1986 was the general acceptance of the failure of collectivisation in both agricultural and industrial sector. In 1988, the 
government issued the Resolution 10, which contained the guidelines for the decollectivisation of agriculture. Given the fact that about $80 \%$ of the population was living at that time in rural areas, this and the crop market liberalisation represented the most important reform for household economy.

According to various authors, (Luong and Unger 1998; Ravallion and Van der Walle 2001, 2003) distribution of farmland to families was carried out in a relatively fair way. The national leadership, in order to maintain socio-political stability, assigned the plots of land among the villagers on a strictly egalitarian way and only a small number of plots were assigned through auctions.

Villagers received the usufruct on the land for 20 years for annual crops and 50 for perennial. While favouring the long-term distribution of use rights, many preferred periodic redistribution in order to maintain equity, a pattern in use in prerevolution village practice. During the period of tenure they could transfer, lend or rent out the use right (Kerkliviet and Selden 1998).

Land concentration was strongly discouraged. The law allowed up to four hectares of annually cropped land per household and local authorities had the option to reduce the size by redistributing the excess. After and distribution, local authorities gave away, sold or contracted capital, draft animals and sideline enterprises to small farmers.

Jointly with the land de-collectivisation, the Vietnamese government started a progressive liberalization of crops markets. The contract system requiring farmers to sell a large part of their output to the state at a low price was replaced with a more market-oriented mechanism. Crop markets and inputs markets were fully liberalised but the State kept the control on export and the marketisation between North and South (Ghosh and Whalley 2004). According to Ghosh and Whalley (2004) the impact of policy reforms resulted in a massive increase in production of rice, maize sweet potatoes and cassava. This was the combined outcome of an expansion in the area cultivated, the more efficient use of chemical fertilizers and in the adoption for rice cropping of more productive methods of cultivation such as the conversion of deep water rice cultivation area to double cropped irrigated rice.

The consequence of these reforms was an increase in income level of rural households. The price liberalisation and land reform fostered the demand of internally produced goods (construction sector products, tools, bicycles, etc.) avoiding an output fall. Furthermore, the gradual price liberalisation created new incentives for farmers and producers of internally consumed goods. The increase in rural household income supported the buoyant growth of the domestic sector (manufacturing and services) and induced domestic producers to substitute previously imported products (Jansen 2002).

This was possible not only thanks to the gradual character of the reform process, but also because the agriculture was not so heavily characterized by the distorted incentives typical of other socialist economies (Lavigne 1999). Differently from the Soviet Union's farms that comprised a huge centralized infrastructure, Vietnamese communes had relied since early 1980s on the household's economy and incentives were similar to those of cooperatives (Kerkvliet and Selden 1998).

Meanwhile, changes in the enterprise laws and the progressive reform in the State Owned Enterprise (SOEs) sector allowed the development of private firms. Further, 
reductions in tariff barriers and FDI controls encourage trade and the inflow of capitals and technology. The reforms have resulted in robust economic growth, averaging 7.9\% during the period 1990-2000 (Glewwe et al. 2002). Even the financial crisis of 1997 did not affect the Vietnamese economy significantly although it led to some reductions in FDI originated from Asian countries. In passing, it is noted that throughout the reform period, employment growth has been low, particularly in the manufacturing sector. This is partly attributable to the small share of industrial GDP in Vietnam and partly to the very low elasticity of employment to output growth in Vietnam (Jenkins and Sen 2002; Tarp et al. 2003). Meanwhile, the SOEs have been reducing their labour force.

\section{Growth and income distribution in Vietnam}

The important successes that occurred in the economic growth of Vietnam have been accompanied by a massive reduction of poverty (from $58.1 \%$ in 1993 to $37.4 \%$ in 1998) and by a "tolerable" increase in inequality. The Gini's index measured on consumption per capita data increased from 0.32 in $1992-1993$ to 0.352 in 19971998. The decomposition analysis between subgroups (rural and urban) with Theil's index shows that in 1993 the main contribution to the total inequality is given by the rural inequality (within rural inequality multiplied by the population share in Table 1), followed by the urban inequality and between groups inequality. In 1998, the inequality within groups remains stable and the between group divide increases. The urban-rural gap, therefore, explains most of the increase in the inequality, while the within rural and within urban variations are limited (Glewwe 2004 and Table 1).

Is this phenomenon attributable to a dramatic decrease of rural population? When the urban rural gap increases, one would expect to see increasing migration out of rural areas (Harris and Todaro 1970). As in general more skilled and young workers tend to migrate, the outcome should be a decrease of inequality in rural areas and an increase in urban ones, due to the mass inflow of relatively less skilled and less remunerated workers. In the long-run, this effect should disappear due to the increased competition among wages.

Our analysis of Vietnamese household surveys and various contributions (Liu 2001; de Brauwn and Harigaya 2004) found little evidence in this direction. Excluding those households that have immigrated to urban areas and not registered, for whom there is no information available, data show only a limited variation in the urban rural population shares ${ }^{3}$ (Table 1). De Brauwn and Harigaya (2004), in their analysis of migration, do not observe many whole families migrating. On the other hand, they find an increasing role for seasonal migration in the household budget. The rural households continue to work the land, partially due to the fear of expropriation, but some members, conscious of higher wages paid in the towns, move temporary there, without changing their official residence and sending home their remittances. Thus, if there is a population effect on rural inequality this is

\footnotetext{
3 If we take in to account that from 1993 to 1998 some previously denominated urban areas have been reclassified as urban, the share of households that really moved to urban areas might be even smaller.
} 
minimal or not measurable with the available data. We should investigate other potential explanations.

While the increasing rural urban divide (Litchfield and Justino 2003) and the transformation of labour markets (Liu 2004) received a lot of attention, only few contributions explicitly tried to interpret the stability in rural inequality during 1990s (Benjamin and Brandt 2004; Liu 2001). In particular, little attention was given to the relation among reforms (land reform, market liberalisation), government intervention (infrastructures provision and incentives to disadvantaged areas) and income distribution in rural areas.

Benjamin and Brandt (2004) analyse the impact of rice market liberalization on inequality in rural Vietnam. They show that increased producer prices for rice primarily benefited the poorer and middle-income farmers. Using the factor components decomposition (Shorrocks 1982), they analyse the role of different sources of income (wages, other non-farm revenues, etc.) in determining income inequality. Although their findings are important in confirming that agricultural income is not the primary source of income inequality in rural areas (around 26\% on national scale), the analysis is not complete. Their decomposition cannot take into account the direct contribution on income of many important non-monetary elements like infrastructure, education, location that in general play an important role in determining the well being of households.

Using the Oaxaca (1973) methodology, Glewwe et al. (2002) decompose the change in per capita consumption from 1993 to 1998 into changes in family characteristics and changes in the returns to these characteristics. The results show that the increasing gaps are almost completely explained by changes in the returns. Highly educated people and household heads working in secondary or tertiary sectors benefited more than others as they experienced substantial increases in the returns to characteristics. This study focuses on what determine changes in the average consumption level, not consumption inequality.

Heltberg (2003) proposes a regression-based decomposition using the coefficients of an earnings function, but he does not focus specifically on rural areas. Considering rural and urban areas together is difficult. For example is not possible to evaluate the importance of specific rural factors in the determination of earnings such as land productivity, capital and some infrastructure variables, available in VLSS only for rural areas and medium size towns. Another important contribution on inequality is the paper proposed by Wagstaff et al. (2003) but they focus only on a very specific dimension of inequality: the malnutrition and the disparity in access to healthcare.

\section{Methodology and data}

To discover sources of inequality in income or consumption, two analytical frameworks can be employed. The first is commonly known as decomposition by population subgroups or by factor components (Shorrocks 1980, 1982). Examples of the subgroup decomposition include male-female or white-black divides, which produces what is called within- and between-group contributions. Policy implications from this kind of decomposition are limited because the contributions cannot 
be attributed to the dividing variable such as sex or race alone when other variables such as education and experience are not controlled for (Shorrocks and Wan 2005).

On the other hand, decomposition by factor components is often used to attribute total income inequality into components associated with wage income, investment income, and other incomes. These factor incomes are functions of more fundamental variables such as wealth holding, human capital, family characteristics and residential location. It is desirable, particularly from policy-maker's point of view, to identify contributions by these more fundamental variables.

The second analytical framework-regression based decomposition-was initiated by Oaxaca (1973) and Blinder (1973) and extended by Juhn et al. (1993) and Wan (2004). A major advantage of this approach is that other variables can be controlled for thus the contributions of fundamental variables to total inequality can be isolated with little contamination. Early development of this framework is restricted in the sense that it only permits decomposition of income or wage difference between two population groups.

Recent work of Wan (2004) relaxes this limitation and leads to an inequality accounting technique where inequality of income or consumption can be attributed to fundamental variables.

\subsection{The Shapley's value decomposition}

Let $Y=F(X, e)$ be a parametric regression model in which $Y$ is income or a transformation of original income, $X$ is a vector of income determinants or their proxies, and $e$ is the disturbance term. Assuming the presence of a constant term $\alpha$ in the regression model, $Y$ can be written as

$$
Y=a+\tilde{Y}+e
$$

where $\tilde{Y}=\sum \beta_{i} X_{i}=\sum Y_{i}$ is the income flow from various determinants and every $Y_{i}$ is income ${ }^{i}$ flow from the $i$ th factor.

We can say that $\hat{Y}=a+\tilde{Y}$ is the deterministic part and $e$ the stochastic. Total inequality is given by $I(Y)$, where $I$ denotes an inequality measure and $Y$ corresponds to the original income variable. The objective of the regression-based decomposition is to attribute $I(Y)$ to the various components of the $X$ vector, the constant $\alpha$ and the residual $e$.

Shorrocks (1999, Unpublished Manuscript) and Wan (2004) develop a procedure that is not dependent on the inequality measure and not restricted to a particular form of the regression model. To explain this approach, we use the Gini's coefficient as a measure of inequality. We follow the same ordering used by Wan (2004). We first explain how to calculate the contribution of the unobserved element $e$, then the constant $a$ and eventually the contribution of every element $\beta_{i} X_{i}$.

Using

$$
Y=a+\sum_{i} \beta_{i} X_{i}+e
$$

and simply applying the Gini's index on both sides of the equation we eliminate the contribution of $e$ (that is white noise) and of constant $a$. 


$$
G(Y)=0+\sum_{i} E\left(Y_{i}\right) / E(Y) C\left(Y_{i}\right)+0
$$

We know from Wan (2004) that the unobservable does affect the underlying income density function and thus inequality. Moreover, the Gini's index declines (increases) when a positive (negative) constant is added to every income recipient. It follows that is inappropriate to use Eq. 3 for inequality decomposition because both these effects are not considered.

To account for the contribution or the residual term, we follow the procedure in Shorrocks (1999, Unpublished Manuscript) and (Wan 2004) and eliminate $e$ from Eq. 2. Hence, we have

$$
\begin{gathered}
Y(e=0)=\hat{Y} \\
G(Y \mid e=0)=G(\hat{Y})
\end{gathered}
$$

The contribution of $e$ to $G(Y)$ is defined as

$$
C O e=G(Y)-G(\hat{Y})
$$

Despite the fact that the expected values of $Y$ and $\hat{Y}$ are identical, $G(Y)$ and $G(\hat{Y})$ can be written as:

$$
\begin{aligned}
G(Y) & =\sum_{i} E\left(Y_{i}\right) /\left.E(Y) C\left(Y_{i}\right)\right|_{\text {rank by }} Y \\
G(\hat{Y}) & =\sum_{i} E\left(Y_{i}\right) /\left.E(Y) C(Y)\right|_{\text {rank by }} \hat{Y}
\end{aligned}
$$

The only difference between (7) and (8) is the ranking of $Y_{i}$ in calculating $C\left(Y_{i}\right)$, the concentration index. Having identified the contribution of the residual to total inequality, we turn to the identification of the contribution of the constant term.

Using the deterministic part $\hat{Y}=\tilde{Y}+a$ and applying Gini

$$
G(\hat{Y} \mid a=0)=G(\tilde{Y})=\left.\sum_{i}\left(E\left(Y_{i}\right) / E(\tilde{Y})\right) C\left(Y_{i}\right)\right|_{\text {rank by }} \hat{Y} \text { or } \tilde{Y}
$$

it follows that the contribution of the constant term can be defined as

$$
C O_{\mathrm{a}}=G(\hat{Y})-G(\tilde{Y})
$$

Finally, the contributions of the various terms in the vector $X$ is given as

$$
C O_{\tilde{Y}}=G(\tilde{Y})=\left.\sum_{i}\left(E\left(Y_{i}\right) / E(\tilde{Y})\right) C\left(Y_{i}\right)\right|_{\text {rank by }} \hat{Y} \text { or } \tilde{Y}
$$

where $\left.C O_{i}=E\left(Y_{i}\right) / E(\tilde{Y})\right)\left.C\left(Y_{i}\right)\right|_{\text {rank by }} \hat{Y}$ or $\tilde{Y}$ is the contribution of the $i$ th variable.

In general, a contribution is interpreted to measure the effect on total inequality if a particular variable or income source is eliminated. Elimination could mean either removal or assuming an even distribution of the relevant variable among all income recipients. If inequality increases (decreases), this source or variable makes a negative (positive) contribution and it is inequality-reducing (inequalityincreasing). 
The procedure, although simple to be programmed, ${ }^{4}$ is extremely timeconsuming the more the number of variables to be considered increases. Given the limited capacity of our computers to complete the calculations in a reasonable amount of time, we opted to reduce the number of variables passing from the estimation model to the decomposition and aggregated the variables into macro classes showing homogeneous characteristics (for details see Sect. 7).

\subsection{The econometric model}

In this paper, inequality of consumption expenditure rather than income is analysed. As argued elsewhere consumption is considered a better measure of human wellbeing. Also, relative to the income variable, consumption shows less volatility as it is not so vulnerable to idiosyncratic shocks. According to Deaton (1997), consumption data are less influenced by measurement errors, particularly for rural households.

To decompose consumption inequality using the regression-based technique, it is necessary to estimate a consumption model. Since consumption expenditure is a function of income and wealth, it is justified to include wealth indicators and other income-generating factors as independent variables:

$$
\log (\mathbf{Y})=\alpha+\delta \mathbf{D}+\beta X+u
$$

Equation 12 is a standard semi log model, where D denotes a set of dummy variables and $\mathrm{X}$ is a vector of non-dummy variables. The use of semi-log functional form follows from the human capital literature and is adopted here to ensure that predicted consumption is non-negative. Variables to be considered are listed in column 2 of Table 3 and are discussed below. In order to maintain the highest level of comparability between the two survey rounds, we took a lot of care in constructing variables in an identical manner. This implied that many potentially interesting data at community level collected in 1998 only, could not be used because of the lack of comparable variables in 1993 .

All continuous variables are in per capita terms, in order to mitigate heteroskedasticity. In addition, household size is added to control for possible scale economies in the household consumption (Deaton 1997). Income determinants include average education, age of household head, the dependency rate (age $<14 \&$ age $>60$ ) and the percentage of members below 10 years in the household, to control for very numerous and young households.

To avoid simultaneity and capture capital depreciation or appreciation, the stock of capital at the beginning of the year (that is, the beginning of income generating process) is used and valuated at year-end prices. Regarding land, both quantity and quality are considered. The former is given by per capita land and zero indicates landlessness, the type of crop mainly cultivated by farmers gives the latter.

\footnotetext{
4 The program written in Java is available for downloading at http://www.wider.unu.edu/decom/ decomp.htm.
} 
We included these dummies in order to investigate the role of crop diversification on income. Our insight is that households achieving to cultivate tradable crops, if the market conditions are favourable, tend to be better off than household that limits themselves to rice auto-production or to other cereals auto-production (grains, etc.). Also, the movement out of rice might suggest the increasing importance in that area of rice/food markets which permits some farmers to stop growing their own food, shifting to a more remunerative cropping pattern (Benjamin and Brandt 2004). Nonfarming employment opportunities help household to diversify income sources and mitigate income risks. This is represented by the proportions of employed in secondary and tertiary sector in the household labour force.

In addition, we included a dummy for ethnicity to control for discrimination and social exclusion that characterise some ethnic groups (Glewwe et al. 2002). In this case we did not consider the Chinese minority to be included in ethnic minorities. First, because very few members of the Chinese minority live in rural areas, while almost all of them are concentrated in towns. Secondly, the Chinese community shows levels of consumption that are far above the average and is particularly active in the most dynamic sectors (i.e. trade and services). After a long period of social exclusion caused by the Vietnam's bad relationship with China, the treatment of this group can no longer be labelled discriminatory.

Credit access, defined as the amount of credit transactions in the previous year, is crucial for consumption smoothing and income generation. Observations are also available on facilities at the commune level that will be used to capture community infrastructure effects Community infrastructure is important for income generation and consumption. Variables used to capture this include presence of sewer system supply, access to electricity, housing (permanent and semi-permanent) and the distance from the first healthcare centre. Finally, commune dummy variables are included in the model to capture location effects.

The data used are extracted from the two waves of the Vietnamese Living Standard Survey, 1992-1993 and 1997-1998. The sample contains detailed record on production and consumption for 3,839 (1993) and 4,266 (1998) rural households. Variables in value terms are deflated by regional price index, thus differences in price levels across regions are eliminated. The consumption functions for 1993 and 1998 were estimated with heteroskedasticity corrected using the popular procedure of White (1980). The 1998s model, to keep the sample nationally representative, was estimated using sampling weights.

\section{Econometric results}

Tables 2 and 3 presents the mean of the variables and the estimation results, respectively (location dummy variables are not shown to economize space). Overall, the fitted models show good $R^{2}$. All parameters possess the expected signs and most of them are significantly different from 0 at the $5 \%$ level of significance.

Although the magnitudes of some estimates changed from 1993 to 1998, they maintain the same signs when non-significant estimates are ignored. It is interesting to note that most of the economic relevant variables not significant in 1993 (dummy 
Table 2 Variables means

\begin{tabular}{|c|c|c|}
\hline Means & 1993 & 1998 \\
\hline Log of household expenditures per capita & 7.34 & 7.65 \\
\hline $\mathrm{Km}$ from 1 st health care center & 9.48 & 4.37 \\
\hline Dummy for permanent house $1=$ having & 0.03 & 0.09 \\
\hline Dummy for semi-permanent house $1=$ having & 0.57 & 0.61 \\
\hline Dummy sewer system, $1=$ having & 0.47 & 0.78 \\
\hline Dummy for having electricity $1=$ having & 0.39 & 0.72 \\
\hline Household size & 4.97 & 4.80 \\
\hline Proportion of young people in household & 0.27 & 0.23 \\
\hline Dependency rate & 0.43 & 0.40 \\
\hline Household head education in years & 5.96 & 6.31 \\
\hline Household head age in years & 44.85 & 47.18 \\
\hline Dummy for ethnic minority $1=$ ethnic minority & 0.14 & 0.16 \\
\hline Proportion of empl. In secondary tertiary sector, in lab force household & 0.16 & 0.24 \\
\hline Value of capital per capita (million dongs) & 0.10 & 0.27 \\
\hline Land for annual and perennial crops per capita $(0=$ landless $)$ & 0.87 & 0.84 \\
\hline Coffee dummy $1=$ having & 0.01 & 0.02 \\
\hline Palm dummy $1=$ having & 0.04 & 0.09 \\
\hline Fruit trees dummy $1=$ having & 0.14 & 0.17 \\
\hline Industrial crop $1=$ having & 0.02 & 0.15 \\
\hline Oth. Crops non rice and non maize $1=$ having & 0.14 & 0.10 \\
\hline Credit received during the previous year and invested (million dongs) & 0.13 & 0.46 \\
\hline
\end{tabular}

Source: Authors calculation and VLSS 1993-1998

for permanent house) or with the wrong sign (crop dummies) became significant or with the right sign in 1998. This corroborates well with the increasing relevance of market forces in transitional economies as reform proceeds, making the incomegenerating model more accurate in describing the rural economy (as confirmed by the increase in $R$ square).

Per capita expenditures decrease with the proportion of non-labor force members in the household, in particular when the household composition is characterized by a high proportion of children. The dummy for ethnic groups shows that ethnic minorities are worse-off but there is a decline in the elasticity, suggesting some improvements. Similar findings are obtained by Heltberg (2003) and Baulch and Minot (2004). More social-oriented studies (Gunewardena and Van der Walle 2000; Baulch et al. 2001) while suggesting some improvements during 1990s, confirm the existence of this discrimination.

Education raises expenditures although the returns are not particularly high. ${ }^{5}$ It is interesting to note that in 1998, thanks to a more market-oriented environment, the return on education increases and the function assumes the expected Mincerian-type form with declining returns on age (though non-significant). This increasing

\footnotetext{
5 One year of schooling increases only of $2.6 \%$ the household income in 1998.
} 
Table 3 Estimated consumption functions

\begin{tabular}{|c|c|c|c|}
\hline Variable group & & 1993 & 1998 \\
\hline \multirow[t]{9}{*}{ Infrastructures } & $\mathrm{Km}$ from 1 st health care centre & $\begin{array}{l}-0.0005104 \\
-0.21\end{array}$ & $\begin{array}{l}-0.0029483 \\
-1.6\end{array}$ \\
\hline & \multirow[t]{2}{*}{ Dummy for permanent house } & 0.00644 & 0.26876 \\
\hline & & 0.18 & $10.10^{* *}$ \\
\hline & \multirow[t]{2}{*}{ Dummy for semi-permanent house } & 0.17357 & 0.14496 \\
\hline & & $11.53 * *$ & $9.81 * *$ \\
\hline & \multirow[t]{2}{*}{ Dummy sewer system, $1=$ have } & 0.10016 & 0.1147 \\
\hline & & $6.25 * *$ & $7.31 * *$ \\
\hline & \multirow[t]{2}{*}{ Dummy for having electricity } & 0.13727 & 0.12978 \\
\hline & & $7.63 * *$ & $7.43 * *$ \\
\hline \multirow[t]{6}{*}{ Household structure } & \multirow[t]{2}{*}{ Household size } & -0.05145 & -0.0709 \\
\hline & & $-12.89 * *$ & $-20.18^{* *}$ \\
\hline & \multirow[t]{2}{*}{ Proportion of young people in household $(<10)$} & -0.33184 & -0.28925 \\
\hline & & $7.50 * *$ & $7.28 * *$ \\
\hline & \multirow[t]{2}{*}{ Dependency rate } & -0.07229 & -0.08329 \\
\hline & & $-2.02 *$ & $-2.67 * *$ \\
\hline \multirow[t]{2}{*}{ Education } & \multirow[t]{2}{*}{ Household head education in years } & 0.0227754 & 0.0264582 \\
\hline & & $12.23 * *$ & $14.70^{* * *}$ \\
\hline \multirow[t]{4}{*}{ Age } & \multirow[t]{2}{*}{ Household head age in years } & 0.00646 & 0.00814 \\
\hline & & $2.17 *$ & $2.57^{*}$ \\
\hline & \multirow[t]{2}{*}{ Square of household head age in years } & -0.00005 & -0.00006 \\
\hline & & -1.61 & -1.88 \\
\hline \multirow[t]{2}{*}{ Ethnicity } & \multirow[t]{2}{*}{ Dummy for ethnic minority } & -0.19964 & -0.10025 \\
\hline & & $-8.14 * *$ & $-4.39 * *$ \\
\hline \multirow[t]{2}{*}{ Labour opportunities } & \multirow{2}{*}{$\begin{array}{l}\text { Proportion of empl. In secondary tertiary } \\
\text { sector, in lab force household }\end{array}$} & 0.19679 & 0.1746 \\
\hline & & $7.12 * *$ & $8.89 * *$ \\
\hline \multirow[t]{2}{*}{ Capital } & \multirow[t]{2}{*}{ Value of capital per capita } & 0.06456 & 0.0401 \\
\hline & & $2.89 * *$ & $4.17 * *$ \\
\hline \multirow[t]{2}{*}{ Land } & \multirow{2}{*}{$\begin{array}{l}\text { Land for annual and perennial crops } \\
\text { per capita }\end{array}$} & 0.05895 & 0.03636 \\
\hline & & $7.80 * *$ & $6.28 * *$ \\
\hline \multirow[t]{10}{*}{ Land quality } & \multirow[t]{2}{*}{ Coffee dummy } & 0.0727 & 0.14019 \\
\hline & & 0.7 & $3.48 * *$ \\
\hline & \multirow[t]{2}{*}{ Palm dummy } & 0.10272 & 0.04639 \\
\hline & & $3.02 * *$ & $2.27 *$ \\
\hline & Fruit trees dummy & 0.0277 & 0.00862 \\
\hline & & 1.56 & 0.53 \\
\hline & Industrial crops dummy & -0.01644 & 0.02139 \\
\hline & & -0.44 & 1.14 \\
\hline & Oth. crops non rice and non maize & -0.02808 & 0.02269 \\
\hline & & -1.56 & 1.1 \\
\hline Credit access & Credit received during the previous year & 0.12811 & 0.03235 \\
\hline & and invested & $5.03 * *$ & $3.48 * *$ \\
\hline
\end{tabular}


Table 3 continued

\begin{tabular}{lcc}
\hline Variable group & 1993 & 1998 \\
\hline Constant & 6.96955 & 7.42307 \\
& $94.77^{* *}$ & $91.36^{* *}$ \\
Observations & 3,839 & 4,266 \\
$R$-squared & 0.53 & 0.58 \\
\hline
\end{tabular}

Robust $t$ statistics in parentheses

* Significant at 5\%; ** Significant at $1 \%$

importance of education, given the fact that the disparities in educational attainments are relevant and will probably widen due to the progressive privatization, raises some concern about the future. Van der Walle's (2000) finds strong complementarities among education and returns on infrastructures and a general synergy between human and physical capital. This implies that the poorly educated will obtain systematically lower returns to investments and infrastructures. From this, the author argues that without a renewed effort in providing education, in the long-run, given the actual disparities in education, inequality will increase dramatically.

The coefficients for secondary and tertiary sector workers in the household are positive and the elasticity slightly increases between the 2 years driven by the increase of workers in the two sectors (Table 2). This suggests a higher return in non-farm activities due to the decline of agriculture as a main source of household income. Gallup (2004) argues that this declining share of agriculture as the economy grows will raise inequality because non-farming incomes tend to be more unevenly distributed. This will occur unless the within-sector inequality in the nonagricultural sectors falls substantially due to a permanent movement of labor out of farming (Gallup 2004).

Apparently this process seems very slow because the capacity of industrial sector to employ new workers is limited and most of the new non-agricultural jobs are short-term and in the low value added services sector. Jenkins and Sen (2002) calculate, comparing to other South East Asian manufacturing sectors, that Vietnam recorded the lowest elasticity of employment to output growth (0.20): between 1990 and 2000 out of 6 millions new jobs only $10 \%$ were in manufacturing sector against 1 million in agriculture and the rest in low-value added services.

The value of capital is positive and significant as well as land. These results need a particular attention, given the fact that they represent the main household's assets. As we previously noted, land distribution was egalitarian and there is no evidence of significant worsening during 1990s (Ravallion and Van der Walle 2003). Nevertheless, in particular in Mekong Delta the number of landless increased (WB 2004). ${ }^{6}$ Our results show a decrease in the consumption- on- land elasticity

\footnotetext{
${ }^{6}$ Figures (WB 2004) show that a considerable part of the increase in landless is because the better-off households increasingly rely less on land as a source of income. With the only exception being Mekong Delta, where landlessness is more prevalent in poor households, all regions show that richer households tends to finance a higher level of expenditures (or an investment) with the sale of the land.
} 
between 1993 and 1998, confirming the previously evidenced decline in agriculture importance and in the land as main asset.

On the other hand, the return on capital significantly increases because of the slow movement towards mechanization and the increasing demand for it. Due to the limited size of agricultural plots and the low-cost labour supply, Vietnamese agriculture is extremely labour intensive and undercapitalised. Until now for example, mechanical power technologies have not been introduced as extensively as with other Asian neighbours, especially for land preparation and threshing (Pingali et al. 1997). Besides the comparative advantage still represented by labour force, the main obstacle to the mechanisation of agriculture has been the high cost of capital and limited credit access. However, in the long-run, the combined effect of rising wages and the liberalization policies surrounding machinery imports will help alleviate the current bottlenecks.

Moreover, our estimation results show that cropping diversification starts to pay a higher return the more agriculture produces for export (late 1990s). The dummy for coffee, a cultivation introduced massively in Central Highlands since 1995, becomes positive in 1998 thanks to the strong commitment of government to foster its export and to help resettlement in area where coffee can be grown. The other crop dummies assume a positive sign in 1998, but only the palm dummy is significant.

The non-significance of the fruit tree dummies can be explained by the fact that these crops have been planted only in mid 1990s and, typically, they have three- tofive lags in revenue generation. These results confirm the findings of Benjamin and Brandt (2004) on preliminary modifications (with some lags and regional variations) in the households cropping pattern occurred among 1993 and 1998. Community facilities are clearly important for improving household well-being as access to water; to sewage, system and electricity are all positively related to consumption as well.

Finally, the estimates associated with credit access show an increase in the return on this variable, suggesting a strong demand for it not yet satisfied by the still underdeveloped financial system. One of the main problems of rural households in transition countries is credit and market access (Lavigne 1999). The collapse of state structure has not automatically been followed by the emergence of a private credit sector willing to lend to rural households. Furthermore, post-transition bank systems generally suffer from heavy credit constraints.

In Vietnam, World Bank (2004) observed important improvements during 1990s. Rural households, even the poorest, thanks to micro-finance targeted programs, have had, for the first time, access to significant set of credit institutions. Moreover, several communes, with the help of NGOs run savings and loans schemes. In passing, we notice that the informal sector continues to be of great importance, accounting for close to $50 \%$ of the total micro-credit market. However, this figure might be biased downward. Although the interest rates charged by the informal sector were higher, borrowing rates were significantly higher than in the formal one. In particular, poor households seem to prefer the informal network and in poor communes, few of them seem to save through a formal mechanism (WB 2004). 


\section{Decomposition results}

Since the decomposition procedure is computationally demanding, it is necessary to group some of the terms in the consumption function before running the decomposition program. The variables multiplied by their coefficient are aggregated additively in order to arrive to a more treatable number. From about 20 variables, we obtained 11 groups defined in column 1 of Table 4 . Therefore, the consumption function is rewritten as:

$$
\begin{aligned}
\log (Y)= & \hat{a}+\text { Infrastructures }+ \text { Household Structure }+ \text { Education }+ \text { Age } \\
& + \text { Ethnicity }+ \text { Land }+ \text { Capital }+ \text { Labour Opportunities }+ \text { Land Quality } \\
& + \text { Location }+ \text { Credit Access }+ \text { Residual }
\end{aligned}
$$

where $\hat{a}$ is the estimated constant.

Although the decomposition procedure can be applied with any inequality measure, decomposition results could differ depending on the measure used. Under such a circumstance, it is common practice to choose one particular indicator when discussing analytical results. Given its popularity, the Gini's coefficient will be employed hereafter in this paper. Results under other measures are presented in Tables 4 and 5 but will not be discussed.

Referring to column 3 of Tables 4 and 5 it is clear that the most important determinant of inequality in rural Vietnam is location. The importance of location in economic development is long recognised and is more recently highlighted in the new economic geography theory. For countries like Vietnam where farmers derive a considerable amount of income from farming, the location variable must be crucial as it reflects climatic and geographic conditions. Needless to say, isolated areas are typically poorer and lag behind in development.

The second most important contributor is community facilities. More interesting is that the contribution increases from 1993 to 1998 . As community facilities are largely provided by local government, this finding indicates a growing gap in financial capacities of local governments. Development economists may argue that community investment should be biased towards the poor but this clearly is not the case in Vietnam. It is perhaps a unique feature of the transition process that decentralization weakens or even reverses the redistributive impact of government or public investment. These results are supported by the public economics literature that decentralisation may well bring about negative impact on spatial inequality (Prud'homme 1995).

It is worth analysing together the decline in the contribution of location and the increase of infrastructures among the 2 years (Tables 4 and 5). We consider this result not coincidental. Looking at the rates of growth of rural consumption in the North and South Vietnam ${ }^{7}$ and among the seven regions there is some evidence of convergence if we exclude Ho Chi Mihn region performance (Liu 2001). Thus,

\footnotetext{
7 In North Vietnam we include Northern Uplands, Red River Delta, Northern Coastal, in South Southern Coastal, Central Highlands, Ho Chi Mihn and Mekong Delta.
} 


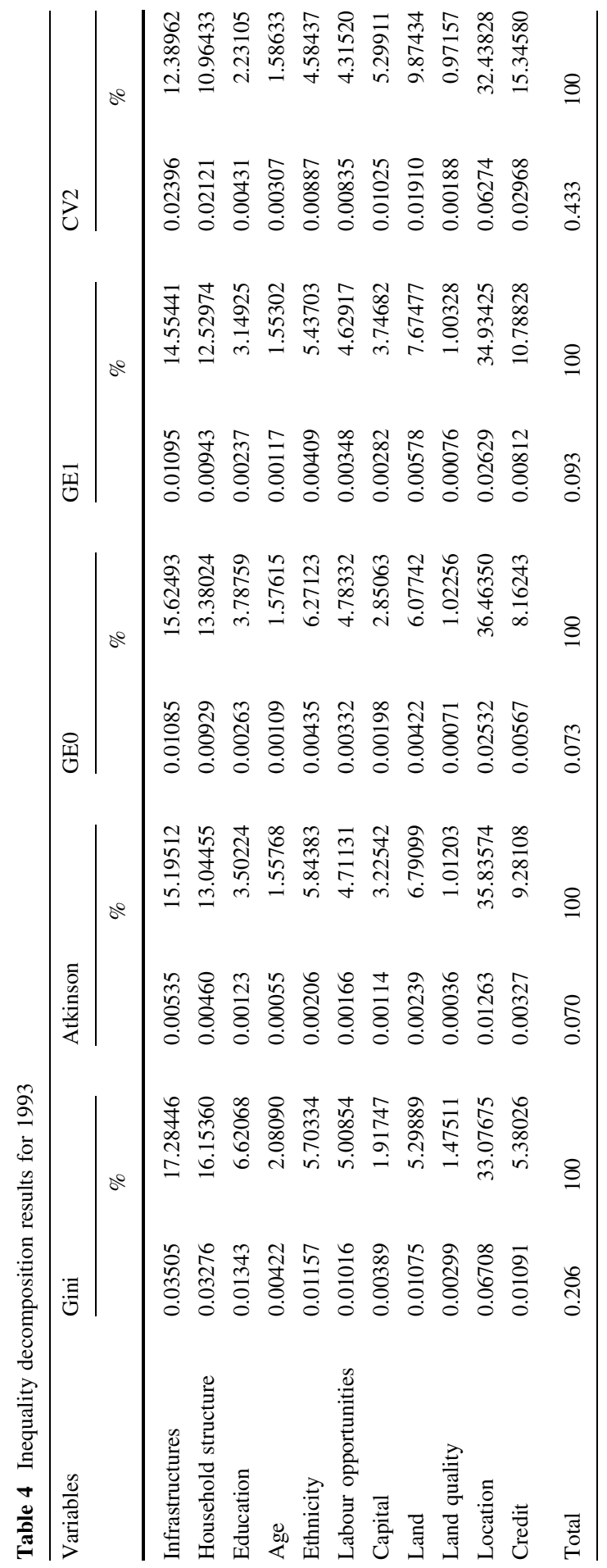




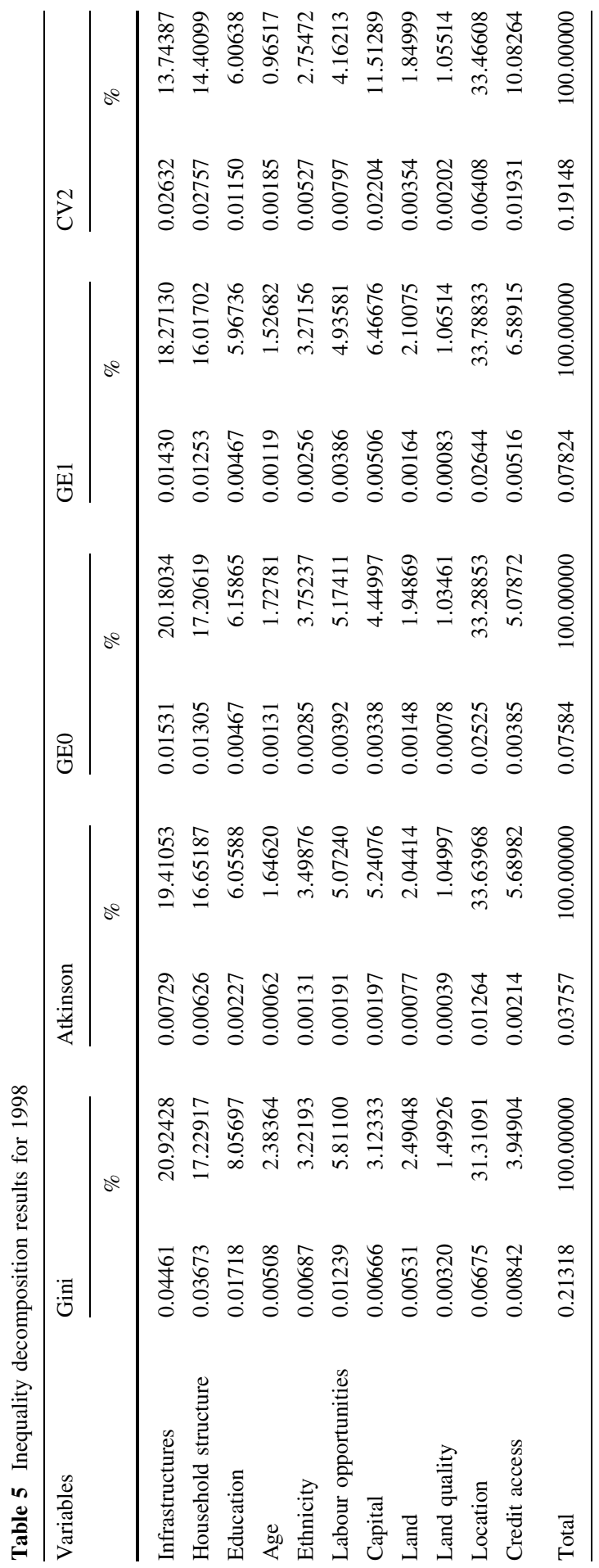


there is a declining role played by the pure geography, while the infrastructures gain some momentum because, the fast growing areas Ho Chi Mihn and Red river Delta are those more urbanised and better endowed with facilities, electricity, sewer systems, roads, etc. Generalising this result, in the long-run and without corrective interventions, we might observe a reduction in the gap among rural North and South, less homogeneity within regions and an increasing divide among areas with or without infrastructures.

The third and fourth components are represented by the household structure and education. Both tend to increase in 1998, but from a political point of view, the increase of the education contribution deserves a particular attention. Van der Walle's (2000) analysis previously mentioned is based on 1993s data and at that time, the uneven distribution of education was already creating some concerns. The 1998s situation further supports this view, confirming the urgency of government's corrective intervention. The human capital, in fact, is not only important in it but as evidence shows (Van der Walle 2000); the full return on infrastructures will not realised by the poor without a concomitant effort in improving education.

The total inequality attributable to land, as expected, is limited, suggesting two important conclusions. First, the land reform was successful in fairly distributing this asset and the positive effects tend to be persistent (Ravallion and Van der Walle 2003). Also, as evidenced by Benjamin and Brandt (2004), the declining role played by land implies that farming had become less important in affecting consumption and inequalities.

The same cannot be said about capital, though its contribution is small. At present, the dominant input in rural Vietnam is labour with limited use of machinery or other capital input. However, the Chinese experience demonstrates that once farmers start to diversify into non-farming activities, capital will fast become the most crucial factor in both income or consumption generation and inequality (Wan 2004). We interpret the increase in the inequality contribution (Tables 4 and 5) as preliminary evidence in this direction. This variation confirms that, due to partial liberalisation of machinery market, in some area of the country is starting an embryonic mechanisation (Pingali et al. 1997). Cleary households with a better access to credit and enough landholdings to exploit economies of scale are favoured. Regarding credit, the decline in the contribution is encouraging and shows that during 1990s the joint effort of NGO's, government and World Bank to set up rural bank and micro-finance institutions was successful.

Finally, it is worth noting the increase of labour farm activities as a source of inequality and the decline of ethnicity. The first moves in the expected direction with an increase among the 2 years as suggested by other authors. Nevertheless, the magnitude of the contribution is limited as compared to Gallup (2004), Benjamin and Brandt (2004) decomposition, because we control for other factor not includable in a factor-components analysis. Regarding ethnicity, although the decline is significant, such a contribution deserves serious policy consideration. As argued by Kanbur et al. (2005), ethnicity-induced inequality cannot be taken on its face value; it may cause ethnic tensions even unrest. 


\section{Conclusions}

By combining the Shapley's value technique of Shorrocks (1999, Unpublished Manuscript) and regression based decomposition framework of Wan (2004), this paper explores the composition of inequality in rural Vietnam and analyses its modification between 1993 and 1998. Although total inequality in rural Vietnam more or less remained stable in the period considered, interesting changes are found with regard to the individual components associated with various inequality determinants.

Our results demonstrate that, human capital, physical capital, infrastructures and household structure gained importance while other factors lost ground in determining rural inequality. Based on the empirical results, a number of policy implications or recommendations can be made to tackle the potential inequalityincreasing elements.

A well-implemented and egalitarian land reform seems to have had positive and persistent consequences on rural income distribution. The same can be said about polices targeted to increase the access to credit in rural areas. In both case we observe a low and declining contribution to inequality.

Besides that, the central government must take measures to abate the regressive nature of public investment in community infrastructures. Poor communities deserve special support in the provision of infrastructure, preferably inversely linked to the financial status of the local governments. Similarly, adequate arrangement should be made to ensure equal access to education in poor areas given the increasing contribution of this variable to total inequality.

Finally, government should intervene to eliminate the distortions created by the actual distribution of capital and non-farm opportunities. There is a problem of incentives in the sense that private manufacturing sector (due to poor access to credit) is still not able to absorb the surplus agricultural labour force. This makes labour force cost in agriculture particularly competitive and discourages the introduction of machinery. The consequences are an increasing inequality generated by non-farm revenues, accessible only for a limited part of the population, and a slow increase of higher value added activities.

Acknowledgements The authors acknowledge Giovanni Andrea Cornia of University of Florence, the editor and the anonymous referee for useful comments and suggestions. The usual disclaimer applies.

Open Access This article is distributed under the terms of the Creative Commons Attribution Noncommercial License which permits any noncommercial use, distribution, and reproduction in any medium, provided the original author(s) and source are credited.

\section{References}

Alesina A, Perotti R (1996) Income distribution, political instability, and investment. Eur Econ Rev 40(6):1203-1228

Blanchard O, Kremer M (1997) Disorganization. Quart J Econ 112(4):1091-1126

Blinder AS (1973) Wage discrimination: reduced form and structural estimates. J Hum Resour 8:436-455 
Baulch B, Truong TK, Chuyen D, Haughton J (2001) Ethnic minority development in Vietnam: a socioeconomic perspective. Policy Research Working Paper 2836. The World Bank, Washington, $\mathrm{DC}$

Baulch B, Minot N (2004) The spatial distribution of poverty in Vietnam and the potential for targeting. In: Dollar D, Glewwe P, Agrawal N (eds) Economic growth, poverty and household welfare in Vietnam. The World Bank, Washington, DC

Boeri T (2000) Structural change, welfare systems, and labour reallocation lessons from the transition of formerly planned economies. Oxford University Press, Oxford

Cornia GA, Popov V (2001) Transition and institutions: the experience of gradual and late reformers. Oxford University Press, Oxford

De Brauwn A, Harigaya T (2004) Seasonal migration and improving living standards in Vietnam. mimeo

Deaton A (1997) The analysis of household surveys: a micro-econometric approach to development policy. Johns Hopkins University Press, Baltimore and London

Dutta M (1995) Vietnam marketization and internationalization of its economy. J Asian Econ 6(3):311326

Benjamin D, Brandt L (2004) Agriculture and income distribution in rural Vietnam under economic reforms: a tale of two regions. In: Dollar D, Glewwe P, Agrawal N (eds) Economic growth, poverty and household welfare in Vietnam. The World Bank, Washington, DC

Flemming J, Micklewright J (1999) Income distribution, economic systems and transition. Innocenti Working Papers N.88

Gallup J (2004) The wage labor market and inequality in Vietnam in the 1990s. In: Dollar D, Glewwe P, Agrawal N (eds) Economic growth, poverty and household welfare in Vietnam. The World Bank, Washington, DC

Ghosh M, Whalley J (2004) Are price controls necessarily bad? The case of rice in Vietnam. J Dev Econ 73:215-232

Glewwe P, Gragnolati M, Zaman H (2002) Who gained from Vietnam's boom in the 1990s? An analysis of poverty and inequalities trends. Econ Dev Cult Change 50(4):773-782

Glewwe P (2004) An overview of economic growth and household welfare in Vietnam in the 1990s. In: Dollar D, Glewwe P, Agrawal N (eds) Economic growth, poverty and household welfare in Vietnam. The World Bank, Washington, DC

Gunewardena D, Van Der Walle D (2000) Sources of ethnic inequality in Vietnam World Bank Research Paper 2297, The World Bank, Washington, DC

Harris J, Todaro MP (1970) Migration, unemployment and development: a two sector analysis. Am Econ Rev 60:126-143

Heltberg R (2003) Spatial inequality in Vietnam: a regression-based decomposition. Paper presented at the WIDER's conference "Inequality Poverty and Human Well Being"

Jansen K (2002) Economic reform and welfare in Vietnam. In: Lu A, Montes M (eds) Poverty, income distribution and well-being in Asia during the transition". Palgrave Macmillan and UNU-WIDER

Jenkins R, Sen K (2002) Globalization and labor markets in the south. paper presented at the conference "globalization, growth and (in)equality". University of Warwick, March 2002

Kanbur R, Venables T, Wan GH (2005) Spatial disparities in human development in Asia. UNU Press

Kerkvliet TBJ, Selden M (1998) Agrarian transformations in China and Vietnam. The China Journal, No. 40, Special Issue Transforming Asian Socialism. China and Vietnam compared (July) 37-58

Juhn C, Murphy KM, Brooks P (1993) Wage inequality and the rise in returns to skill. J Polit Econ 101:410-442

Lavigne M (1999) The economics of transition: from socialist economy to market economy, 2nd edn. Mac Millan Press, London

Litchfield J, Justino P (2003) Welfare in Vietnam during the 1990s: poverty, inequality and poverty dynamics. J Asia Pacific Econ 2004 9(2):145-169

Liu AYC (2001) Markets, inequality and poverty in Vietnam. Asian Econ J 15(211)

Liu AYC (2004) Gender wage gap in Vietnam: 1993 to 1998. J Comp Econ 32:586-596

Lu A, Verme P (2002) Labour markets in Asian transition economies. In: Lu A, Montes M (eds) "Poverty, income distribution and well-being in Asia during the transition". Palgrave Macmillan and UNU-WIDER

Luong HV, Unger J (1998) Wealth, power and poverty in the transition to market economies: the process of socio economic differentiation in rural China and Northern Vietnam. The China Journal, No. 40, Special Issue Transforming Asian Socialism. China and Vietnam Compared (July 1998) 61-93 
Milanovic B (1995) Poverty, inequality, and social policy in transition economies, Policy Research Working Paper Series 1530. The World Bank, Washington, DC

Milanovic B (1998) Explaining the increase in inequality during the transition. Policy Research Working Paper Series 1935. The World Bank, Washington, DC

Oaxaca RL (1973) Male-female wage differences in urban labour markets. Int Econ Rev 14:693-709

Pingali PL, Khiem NT, Gerpacio RV, Xuan VT (1997) Prospect for sustaining Vietnam's re-acquired rice exporters status. Food Policy 22(4):345-358

Prud'homme R (1995) The danger of decentralization. World Bank Res Obs 10(2):201-220

Roland G (2000) Transition and economics: politics, markets and firms. MIT Press, Cambridge Mass

Ravallion M, Van der Walle D (2001) Breaking up the collective farm: welfare outcomes of Vietnam's massive land privatization. Policy Research Working Paper Series 2710. The World Bank

Ravallion M, Van der Walle D (2003) Land allocation in Vietnam's agrarian transition. Policy Research Working Paper Series 2951. The World Bank

Shorrocks AF (1980) The class of additively decomposable inequality measures. Econometrica 48: $613-625$

Shorrocks AF (1982) Inequality decomposition by factor components. Econometrica 50:193-211

Shorrocks AF, Wan GH (2005) Spatial decomposition of inequality. J Econ Geogr 5(1):59-81

Tarp F, Roland-Holst D, Rand J (2003) Economic structure and development in an emergent Asian economy: evidence from a social accounting matrix for Vietnam. J Asian Econ 13:847-871

Van der Walle D (2000) Are returns to investment lower for poor? Human and Physical Capital Interactions in Rural Vietnam. Policy Research Paper 2425. The World Bank, Washington, DC

Wagstaff A, van Doorslaer E, Watanabe N (2003) On decomposing the causes of health sector inequalities with an application to malnutrition inequalities in Vietnam. J Econom 112(1):207-223

Wan GH (2004) Accounting for income inequality in rural China: a regression based approach. J Comp Econ 32(2):348-363

White H (1980) A heteroskedasticity-consistent covariance matrix estimator and a direct test for heteroskedasticity. Econometrica 48:817-838

World Bank (WB) (2004) Vietnam development report 2004. The World Bank, Poverty Washington, DC 